\title{
Assessing the impact of municipal government capacity on recovery from Hurricane Maria in Puerto Rico ${ }^{\text {ir }}$
}

\author{
Etienne Rosas, Patrick S. Roberts *, Andrew Lauland, Italo A. Gutierrez, Blas Nuñez-Neto \\ The RAND Corporation, Santa Monica, CA, USA
}

\section{A R T I C L E I N F O}

\section{Keywords:}

Disaster recovery

Community engagement

Municipal capacity

Government capacity

Hurricanes

Puerto Rico

\begin{abstract}
A B S T R A C T
A municipality's level of public engagement and especially community involvement is associated with a greater rate of recovery in Puerto Rico following Hurricane Maria in 2017. This finding is based on an analysis of the relationship between the capacity of Puerto Rico's 78 municipal governments and their rates of post disasterrecovery, controlling for both exposure to Maria and pre-storm trends. Municipal capacity for community involvement may help activate social capital and the co-production of disaster recovery. Community involvement may increase trust among local officials and residents, increase government's knowledge of community priorities, and help residents access federal and state aid. Other measures of management capacity are not consistently associated with a faster rate of post-disaster recovery. The findings suggest that investing in municipal capacity for public engagement as part of disaster preparedness may provide benefits for disaster recovery. For researchers, the combination of original survey data and readily available post-disaster indicators provides a model for assessing recovery after disaster in the short term.
\end{abstract}

\section{Introduction}

Large-scale disasters can overtax local government management systems, particularly outside of major metropolitan areas [1]. However, even as they are overwhelmed by major disasters, local governments are essential for identifying recovery priorities and implementing recovery spending and risk reduction. Johnson and Olshansky [2]; 9) emphasize that post-disaster recovery is "best accomplished at local levels of government" because of localities' familiarity with constituents' priorities and needs and the local context. In practice, however, post-disaster recovery efforts "tend to be overly fixated on the management" of assistance programs operating at the federal and state levels [3]; 248). Much of the disaster management scholarly literature focuses on emergent or networked forms of organization for managing complex disasters (e.g., Ref. [4]. Meanwhile, the black box of local government capacity remains relatively underexplored. Government capacity refers to elements of strategy, management, operations, and finance [5]; 293-294). Moreover, with rare exceptions that focus more on resilience that recovery [6, 82], there is little research examining the link between increases in local government capacity and their effect on recovery. Researchers lack empirical evidence showing that increases in local government capacity lead to less damage or faster recovery.

This study explores how municipal capacity affects recovery from natural disasters by analyzing how Puerto Rico's municipalities weathered the effects of Hurricane Maria in 2017. Puerto Rico's governance structure includes 78 distinct municipalities, each with an independent government and individually elected mayor and legislative body. There are no regional intermediary levels of government between the municipal governments and the Government of Puerto Rico (GPR), and in comparison to the continental United States, relatively few services are shared or provided regionally [8]. Furthermore, even when services are provided by the GPR, municipal governments may be more likely to have more granular information about community vulnerabilities and areas of critical need, and as a result have deeper knowledge of how resources should be administrated and services prioritized. Accordingly, the capabilities of the individual municipal governments could be expected to be of particular importance to both limiting initial damage from the hurricanes and recovering from them afterwards. Indeed, the Center for Puerto Rican Studies at Hunter College found that post-disaster recovery depends upon "the local government's ability to

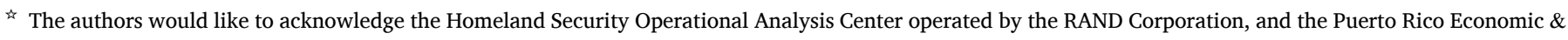
Disaster Recovery Plan project, for support for this research. Dr Gutierrez's work was completed before he joined Amazon.

* Corresponding author.

E-mail address: proberts@rand.org (P.S. Roberts).
} 
prioritize needs and appropriately direct and manage funds and/or available programs" [9].

In 2017 Hurricane Maria devastated Puerto Rico, cutting large parts of the island off from assistance for extended periods of time due to the collapse of the energy grid and communications networks and widespread landslides and floods that destroyed bridges and roadways connecting communities $[8,10]$. Thousands of residents were rendered homeless by the severe damage to housing stock, and response efforts in many cases took days and weeks to reach far flung communities. The territory's 78 individual municipal governments with varying levels of capacity were exposed to a major shock. We examine this case to assess the role of municipal capacity in hastening recovery following a major disaster. For the purposes of this analysis, recovery is defined as the period after the response, when hurricane winds and waters have died down, life-saving activities have slowed, and "during which the longer-term activities of reconstruction, rehabilitation and recovery proceed" [11]; 51).

This article poses two research questions: First, how does municipal capacity affect post disaster recovery? And second, what aspects of municipal capacity have the most significant impact on recovery?

To answer these questions, we operationalize the constructs of municipal capacity and recovery. We measure municipal capacity building off of work by Johnson $[3,13]$. We develop a means for characterizing overall municipal capacity as well as key subcomponents in order to assess the role that overall municipal capacity and specific aspects of capacity, such as management, may play in reducing damages incurred during a disaster and in recovering from disaster more quickly. To control for variance in damages and exposure, we focus on reported housing damages above $\$ 5000$. We also take into account damages which may not be recorded in official estimates as a result of Puerto Rico's informal housing market. We measure recovery using key socio-economic indicators and compare them to their counterfactual had the hurricanes not occurred, based on previous trends. Accounting for this counterfactual is critical in the case of Puerto Rico. Long-term economic decline over the past decade, combined with large-scale population outmigration, make it difficult to interpret indicators that may have continued to decline on their own in the absence of the hurricanes. Finally, we use OLS regression analysis to determine the statistical relationship between capacity and recovery. Fig. 1 shows the analytic approach.

The study finds that public engagement and, in particular, community involvement is positively associated with a greater rate of recovery. Community involvement includes much of what the public administration literature refers to as "co-production" of public services by government and residents: citizen involvement in planning, designing, and delivering services, and government support for community development [14]. Appendix I shows the components of this variable.

The remainder of this paper is organized as follows. The paper begins with a discussion of how the role of municipal capacity and in particular public engagement has been neglected in theoretical and empirical studies of disaster recovery. Then, it explains the process for measuring capacity, damages, and recovery, drawing on relevant literature and prior research. We then present our empirical approach and discuss the data we used to assess municipal capacity, damage from Maria, and recovery after Maria. We present the results of our assessment of how overall municipal capacity and specific components of municipal capacity may have impacted damage to municipalities from Maria and how quickly they are recovering. We discuss the limitations of our analysis, including data availability and potential limitations of the indicators. We end with conclusions summarizing our interpretation of our findings, their implications for disaster assistance funding and future attempts to study recovery from catastrophic disasters, and potential next steps for future research.

\section{Municipal capacity as an underexplored component of recovery}

Disaster recovery is sometimes conceptualized as a stage in a cycle of disaster, following mitigation, preparedness, and response. More broadly, it is a phase in restoring community functioning and well-being [15]. Despite being a core concept in the hazards and disasters field, many scholars have noted that recovery remains undertheorized [16, 17]. Olshansky and Johnson [18] identify the immature state of recovery theory, and point to "time compression" as a concept to show how the recovery period differs from the routine. In the recovery period, there is an intensification of activities that opens up possibilities for change.

Time links recovery to the concepts of resilience and preparedness [19]. Preparedness actions taken before an event can contribute to resilience, which can lead to faster, fuller, and more equitable recoveries.

Individual and social vulnerability according to demographic groups and underlying characteristics can impede resilience and recovery; a large literature explores these topics [20]. Individual contributions to resilience and recovery are often studied at the neighborhood level, reflecting the burgeoning literature on social capital [21]. Social capital and particularly bridging ties across groups has been shown to be associated with improved disaster recovery [22,23,25,26,28].

By comparison, theoretical and empirical attention to the government's role in fostering resilience and recovery is lacking. Scholars have given some attention to the important role that the federal government plays in recovery from large disasters-and the problems that ensue when such aid is delayed or absent [18]. Municipal capacity, however, is less often studied despite the key role that local governments play linking federal government plans and funding with communities and neighborhoods. Aldrich [29] suggests that attention to nonprofits and individual initiative may obscure the role that local governments play in recovery.

Without sufficient capacity, recovery can be slowed because of a backlog of work, or recovery activities may be taken up by outside groups with a poor grasp of local needs. For example, New Orleans's planning department suffered large budget cuts after Hurricane Katrina

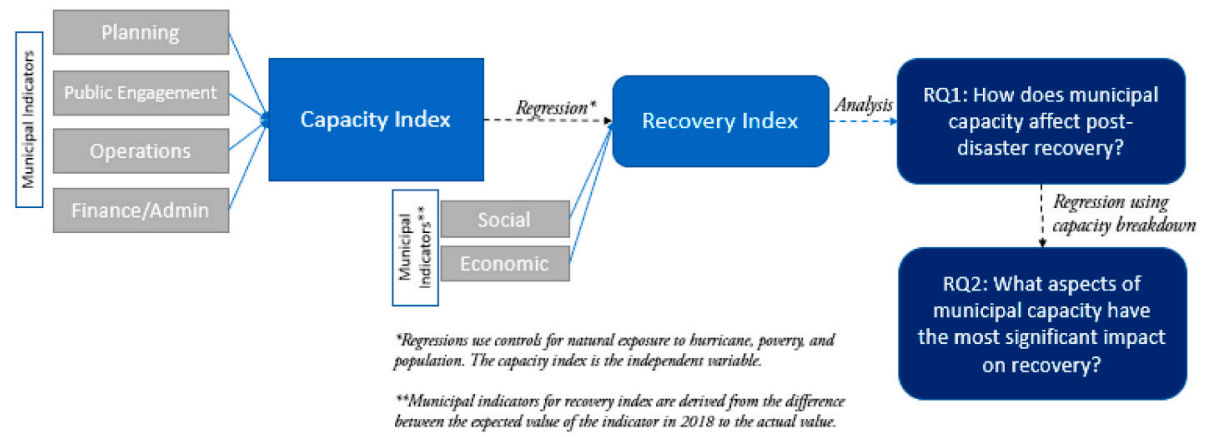

Fig. 1. Analytic approach to municipal Capacity’s impact on recovery. 
[30]. As a result, New Orleans relied on technical assistance from inside and outside the community [32]. The use of outside technical assistance rather than municipal plans and capacity was criticized for not meeting the needs of residents and slowing recovery [33]. However, many governments require substantial technical assistance for many services [34], including after major disasters in order to manage large scale recoveries and access federal aid [18].

It stands to reason that local governments with greater capacity have the ability to process recovery aid from government and nonprofit sources after disaster. More broadly, they may be able to better engage citizens in pre- and post-disaster planning routines to identify priorities and build social capital.

Capacity refers to the ability to achieve some end state, and includes people, money, and other resources. Capacity is a central component of government's ability to address public problems [5]; 293-294; [35]. One part of municipal capacity is the sheer amount of budget and personnel $[12,37]$. Another part of municipal capacity is the ability to engage with the public - a crucial component for targeting aid where it is most needed and helping residents access federal and state government aid more quickly after disaster [38,81]. The terms public engagement and involvement encompass multiple ways to bring people together to address public problems [39]. The public administration and urban planning literature find that governments that engage with and involve the public in the implementation of policy and service delivery have greater impacts than those that do not engage the public $[40,80]$. This finding is robust across many fields, but it has specific manifestations in hazards and disasters contexts $[41,42]$.

To take an example from a specific sector, housing recovery is a linchpin to community recovery. If housing supply takes too long to recover, residents may relocate to new cities, extending the economic disruption by depriving a community of labor and consumers. In island contexts, a lack of housing supply may also limit the number of off island recovery workers who may bring necessary skills [13]. Municipalities' ability to engage with the public may help residents make improvements that limit damage to the housing stock, or plan for alternative housing arrangements and provide mutual support. After Hurricane Katrina, people not evacuated from their residences were more likely to be employed more quickly [43].

Effective recovery depends on capacities developed and actions taken before a disaster occurs - one reason why some scholars have sought to extend the timeline of disaster to include actions before and after an acute event $[44,45]$. Preparedness includes "actions taken in advance of an emergency to develop operational capacity and facilitate and effective response" [46]; 136). The amount and effectiveness of these actions depend on sufficient capacity. One recent theoretical framework for community resilience explains recovery as composed of social capital and cohesion, preparedness and response, and external resources [47]. Local government's role in linking all three deserves further exploration. Municipal capacity may play an important linking role in leveraging the capacities of community members, nonprofits, and the private sector [48]; 29-31).

Finally, our project fills a methodological gap in the literature by developing indices based on data available before and immediately following a disaster. Many resilience frameworks rely on expert judgment or data collected long after an event [49]. The vast majority of approaches consist of fewer than 40 indicators with their selection being based on the following criteria: validity, sensitivity, robustness, reproducibility, scope, availability, affordability, simplicity, and relevance. We offer one method for building indicators in a context where data are limited and perishable.

Moreover, while many disaster recovery frameworks emphasize that pre-disaster mitigation is a substantial determinant of speed and strength of recovery [50,51], most recovery evaluations can only capture snapshots without accounting for preceding trends nor specifying how existing capacities may be impacting progress. Our method uses trend data and standardization techniques to cover these gaps and provide a more realistic and dynamic view of recovery and its relation to specific aspects of capacity. This is crucial for targeting investments in vulnerable locations where systemic failures affect most aspects of capacity.

\section{Measuring capacity and recovery}

Consistent with approaches taken in prior research literature (e.g. Ref. [52], we postulate that capacity and recovery are concepts that cannot be measured using any single metric or even any single category of metrics. Accordingly, we attempt to measure capacity and recovery using indices. ${ }^{1}$ We use standardization techniques to combine these inherently different measures into a common scale. A drawback of this approach is the loss of specificity and the ability to directly interpret scores on the indices. As a result, effect sizes are less meaningful. However, this method allows us to incorporate more elements that the research literature suggests are relevant to the broad concepts of capacity and recovery, while not precluding the identification of broader associations and trends.

\subsection{Measuring municipal capacity}

Several of the authors, in conjunction with a project conducted for the Federal Emergency Management Agency (FEMA) by the Homeland Security Operations and Analysis Center (HSOAC) at the non-profit, nonpartisan RAND Corporation, developed a framework to measure municipal capacity in relation to disasters $[8,13]$.

The framework is consistent with three key functional areas for governments' ability to solve public problems as identified in classic management literature: planning, operations, and finance [5]; 293-294; $[53,54]$. We added measures of public engagement as a fourth category to reflect the consensus among disaster recovery scholars that engagement and information sharing with the public is an important part of capacity. A National Academies [55]; 4) report concluded that "bottom-up interventions - the engagement of communities in increasing their resilience-are essential because local conditions vary greatly."

We measure each municipality's capacity relative to one another in each of these four areas-planning, operations, finance, and public engagement - as well as overall capacity. The measures are based on a subset of 41 indicators based on publicly available data and on data from the Puerto Rico Municipal Capacity Database [13]. Culbertson et al.'s Capacity Index used 49 indicators. We modified the index and dropped eight indicators to avoid multicollinearity when regressing against recovery index and to ensure data source consistency.

An important source of information for the indicators in the Puerto Rico Municipal Capacity Database was the Municipal Survey, which was developed by the International City/County Management Association (ICMA) in consultation with HSOAC, FEMA, and the University of Puerto Rico as part of HSOAC's assessment of municipal government damages, unmet needs, and recovery courses of action following Hurricane Maria [8]. The survey included questions about key aspects of municipal capacity, including which services were offered, staffing, and budgets. Surveys were conducted by onsite research teams in May and June 2018 in all 78 municipalities with a $90 \%$ response rate for key sections related to capacity. Survey responses were self-reported by mayors and other municipal officials.

Other data sources used in the Puerto Rico Municipal Capacity Database include: i) Publicly available yearly financial statements for each municipality; ii) Municipal budget and employment-related data, obtained from the Office of Management and Budget of Puerto Rico (known by its Spanish acronym, OGP); iii) Information on federal grants received by municipalities, obtained from the Puerto Rico Controller's

\footnotetext{
${ }^{1}$ For example, the number of employees working on recovery per capita in a municipality and whether a municipality has a formal recovery plan.
} 
Office; and iv) Information on availability of permit offices, obtained from the Puerto Rico Planning Board. Table 1 in the appendix lists all indicators used in the analysis, the corresponding data source, and the average value for each indicator. Some indicators are coded with one for yes and zero for no. Other indicators are coded with zero for the bottom category and one for the top category, while intermediate categories are coded with an equidistant value. Table 1 in Appendix A presents the possible responses from the bottom category to the top category. Other indicators, such as the annual change in the labor force, are coded with continuous values.

Indicators were grouped by common topics (for example, human resources). and each indicator grouping or topic was assigned to one of the four key functional areas (i.e., planning, public engagement, operations, and finance/administration) to measure relative capacity in those areas in addition to overall municipal capacity. These groupings and assignments are shown in Fig. 2 below and explained in greater detail in Appendix A.

We generated indices through a multi-step standardization process using z-scores to determine each municipality's capacity in each functional area relative to all other municipalities. More specifically we standardized each indicator, and we then standardized the average of the z-scores of indicators assigned to the same functional area. Similarly, to calculate the overall capacity z-score, we standardized the average of the z-scores in each of the four key areas. We are not able to assess whether a municipality has "enough" capacity in any given area, however. We simply measured how much capacity municipalities have relative to one another.

\subsection{Measuring recovery}

Recovery is generally defined specifically in the context of an area that has experienced a disaster [56,57]. For example, in the case of Puerto Rico, the objective of recovery is not simply to return the island to pre-storm conditions-which featured decaying infrastructure, prevalent informal housing, and key public buildings located in flood plains_-but to "build back better." Recovery frameworks borrow from concepts used in the study of resilience, but they are distinct, and neither one should be viewed as a subset of the other (e.g. Refs. [58,59].

We developed a composite measure for recovery which builds on Nuñez-Neto et al. [8]. We chose to focus on recovery in the social and economic dimensions. Data on other dimensions discussed in Nuñez-Neto et al. [8]; such as infrastructure and environment, were not readily available at the municipal level for the time period prior to or after hurricane Maria. Table 1 shows the indicators that were available in both time periods for measuring recovery, the data source for each indicator, and the dates of the pre- and post-hurricane data for each indicator. The indicators in Table 1 are defined in greater detail in the appendix.

For each indicator in Table 1, we define recovery as the deviation of the indicator's actual value in 2018 from its predicted value, which we calculate using a linear prediction based on data from years 2014-2017. It is important to note that we collect 2017 values that mostly precede Hurricane Maria, which made landfall in September 20, 2017, to avoid a downward skew to our hypothetical estimate for 2018 without storm impacts. Several of the indicators we used to measure recovery are reported on a quarterly basis. Accordingly, we chose to include data for the third quarter of 2017 (July-August-September) even though this includes a number of days in September following the impact of Hurricanes Irma and Maria. The alternative would have been to exclude all third quarter data, which would have resulted in excluding the last two full months prior to the storms.

The only exception to collecting values prior to Maria is the standardized mortality rate, for which we use data from 2014 to 2016 and omit 2017 to derive the 2018 prediction (see Table 1); this is because this indicator is provided as a yearly estimate and its 2017 value is skewed downwards due to significant storm effects. Thus, recovery for indicator $j$ for municipality $m$ in year 2018 is defined as:

$\Delta V_{j m}^{2018}=V_{j m}^{2018}-\widehat{V}_{j m}^{2018}$

Where $\widehat{V}_{j m}^{2018}$ denotes the predicted value (V) using a linear trend. Smaller negative deviations indicate that the municipality was able to maintain its previous trend or to return to its previous trends in the aftermath of Hurricane Maria. In other words, it signals higher recovery.

Table 2 shows the mean values and standard error of $\Delta V_{j m}^{2018}$. For crime per capita, standardized mortality rate, and unemployment rate, $\Delta I_{j m}^{2018}$ is expressed as the simple difference as in equation (1). For all the other variables, $\Delta V_{j m}^{2018}$ is expressed as a percentage points of the predicted value (i.e., $\left.\Delta V_{j m}^{2018}=\left[\left(V_{j m}^{2018}-\widehat{V}_{j m}^{2018}\right) / \widehat{V}_{j m}^{2018}\right] \times 100\right)$.

On average, crime rate per capita was significantly lower in 2018 than the predicted value. Studies have found that crime rates can increase after disasters in certain neighborhoods and may be inversely related to recovery activity $[60,61]$. However, a lower than expected crime rate can also be driven by declines in population, lower levels of crime reporting, or less social interaction. Population, labor force, and employment also stand out as, on average, significantly lower in comparison to the predicted trends. The only indicator statistically significant above its predicted value, on average, is quarterly wages. We hypothesize that this may be due to an increase in higher-paying jobs linked to reconstruction and recovery efforts.

We combined all indicators $\Delta V_{j m}^{2018}$ in Table 1 into a single z-score. As in the case of measuring capacity, we standardized each $\Delta V_{j m}^{2018}$ to have mean zero and standard deviation equal to one. Then we averaged all resulting z-scores and standardized this value again to ensure it has a mean of zero and a standard deviation equal to one. The resulting $\mathrm{z}$ score for each municipality $m$ measures the overall relative rate of recovery, which we denote by $r r_{m}$.

\section{Empirical approach to understanding municipal Capacity's relationship to recovery}

We estimate the following linear regression, using data at the municipal level (indexed by subscript $m$ ):

$y_{m}=\alpha+\beta$ Capacity $_{m}+\lambda$ Distance $_{m}+\theta X_{m}+\varepsilon_{m}$

The dependent variable $y_{m}$ denotes our main outcome of interest: recovery. To measure both damages and recovery, our regressions include a set of controls. The first is the distance of each municipality to the path of Hurricane Maria (Distance ${ }_{m}$ ). This variable measures the shortest distance (in $\mathrm{km}$ ) from each municipality centroid to the best track of Hurricane Maria, as provided by NOAA. ${ }^{2}$ We also tried other definitions, such as the average distance of municipalities from the center of the hurricane as it crossed Puerto Rico, and had similar results. The second set of controls, included in vector $X$, control for characteristics of municipalities, such as poverty levels (based on 2016 ACS data), population density (as a proxy for urban versus rural areas), and whether it is a coastal or mountain municipality.

Arguments can be made both in favor of and against controlling for these factors. On one hand, these factors can be important determinants of municipal capacity, and controlling for them may absorb much of the variation we hope to study, biasing our analysis against finding significant results. On the other hand, controlling for them allows us to disentangle the effect of geography, poverty, and differences from being an urban or rural community (for example, geographic factors) from the effects of capacity. The relevant thought experiment is whether two municipalities that have similar levels of poverty, population density,

\footnotetext{
${ }^{2}$ Information on the path of Hurricane Maria can be found here: htt ps://www.nhc.noaa.gov/data/tcr/AL152017_Maria.pdf.
} 
Table 1

Indicators by recovery category.

\begin{tabular}{|c|c|c|c|c|c|}
\hline & Indicator & Justification for use & Source & $\begin{array}{l}\text { Pre-Hurricane } \\
\text { Date (trend) }\end{array}$ & $\begin{array}{l}\text { Post- } \\
\text { Hurricane } \\
\text { Date }\end{array}$ \\
\hline \multirow[t]{3}{*}{ Social } & Population change (\%) & $\begin{array}{l}\text { Outmigration, whether from Puerto Rico or simply to another } \\
\text { municipality, is a sign that conditions in the municipality are } \\
\text { causing citizens to leave; conversely, stable or increasing } \\
\text { population is a sign that the municipality is recovering or doing } \\
\text { well. This indicator is likely associated with quality of } \\
\text { government services, job market/economy, housing stock, } \\
\text { educational opportunities, and infrastructure. }\end{array}$ & U.S. Census & $\begin{array}{l}\text { 2014-2017 } \\
\text { (June) }\end{array}$ & 2018 (June) \\
\hline & $\begin{array}{l}\text { Number of Crimes } \\
\text { Committed per } 1000 \\
\text { inhabitants }\end{array}$ & $\begin{array}{l}\text { Crime rates, especially of the type captured in this indicator, } \\
\text { are a valuable metric of social cohesion. They are related to } \\
\text { quality of law enforcement and effective governance, economic } \\
\text { disparity, and other key community capacities. }\end{array}$ & $\begin{array}{l}\text { Puerto Rico Police } \\
\text { Department. U.S. Census } \\
\text { population. }\end{array}$ & $\begin{array}{l}2014-2017 \\
\text { (Jan-Sept total) }\end{array}$ & $\begin{array}{l}2018 \\
\text { (Jan-Sept } \\
\text { total) }\end{array}$ \\
\hline & $\begin{array}{l}\text { Standardized mortality } \\
\text { rate (SMR) }\end{array}$ & $\begin{array}{l}\text { SMR can be a valid proxy for underlying health of a municipal } \\
\text { population, quality of healthcare infrastructure, and social } \\
\text { support/isolation relative to the rest of Puerto Rico. }\end{array}$ & $\begin{array}{l}\text { Mortality microdata files of } \\
\text { the Puerto Rico Department } \\
\text { of Health }\end{array}$ & $\begin{array}{l}\text { 2014-2016 } \\
\text { (yearly) }\end{array}$ & 2018 (yearly) \\
\hline \multirow[t]{5}{*}{ Economic } & Unemployment & $\begin{array}{l}\text { This standard measure is regularly available and is a widely } \\
\text { used metric of economic health. }\end{array}$ & $\begin{array}{l}\text { Puerto Rico Department of } \\
\text { Labor and Human } \\
\text { Resources }\end{array}$ & $\begin{array}{l}\text { 2014-2017 } \\
\text { (Jan-Sept } \\
\text { Average) }\end{array}$ & $\begin{array}{l}2018 \\
\text { (Jan-Sept } \\
\text { Average) }\end{array}$ \\
\hline & Business Units & $\begin{array}{l}\text { This indicator provides information on how diversified and } \\
\text { active municipal economies are. Beyond employment, which } \\
\text { may be concentrated in certain industries, we also want to } \\
\text { know whether economic recovery is robust enough to sustain } \\
\text { or increase businesses. }\end{array}$ & $\begin{array}{l}\text { Puerto Rico Department of } \\
\text { Labor and Human } \\
\text { Resources }\end{array}$ & $\begin{array}{l}\text { 2014-2017 } \\
\text { (Jan-Sept } \\
\text { Average) }\end{array}$ & $\begin{array}{l}2018 \\
\text { (Jan-Sept } \\
\text { Average) }\end{array}$ \\
\hline & Labor force & $\begin{array}{l}\text { More than high unemployment rates, Puerto Rico has a } \\
\text { problem with low labor force participation rates. Individuals } \\
\text { enter or drop the labor force based on economic opportunities. } \\
\text { Thus, this indicator can be used as a proxy for improvements in } \\
\text { local labor markets. In addition, migration will affect local } \\
\text { estimates of the labor force. Thus, this indicator can also be } \\
\text { used to track outmigration which can potentially be linked to } \\
\text { poor economic prospects. }\end{array}$ & $\begin{array}{l}\text { Puerto Rico Department of } \\
\text { Labor and Human } \\
\text { Resources }\end{array}$ & $\begin{array}{l}\text { 2014-2017 } \\
\text { (Jan-Sept } \\
\text { Average) }\end{array}$ & $\begin{array}{l}2018 \\
\text { (Jan-Sept } \\
\text { Average) }\end{array}$ \\
\hline & Quarterly Wages & $\begin{array}{l}\text { Often in disasters, businesses manage to stay active by } \\
\text { temporarily lowering wages or laying off workers. This, } \\
\text { however, may depress demand and economic activity at large. } \\
\text { Quarterly wages provide a more well-rounded picture of } \\
\text { household finances and overall economic health. }\end{array}$ & $\begin{array}{l}\text { Puerto Rico Department of } \\
\text { Labor and Human } \\
\text { Resources }\end{array}$ & $\begin{array}{l}\text { 2014-2017 } \\
\text { (Jan-Sept } \\
\text { Average) }\end{array}$ & $\begin{array}{l}2018 \\
\text { (Jan-Sept } \\
\text { Average) }\end{array}$ \\
\hline & Employment & $\begin{array}{l}\text { Captures the percentage of workers employed as a share of total } \\
\text { working-age population. It complements our measures of labor } \\
\text { force participation and unemployment by capturing current } \\
\text { labor market conditions, and corresponding more closely with } \\
\text { economic downturn. }\end{array}$ & $\begin{array}{l}\text { Puerto Rico Department of } \\
\text { Labor and Human } \\
\text { Resources }\end{array}$ & $\begin{array}{l}\text { 2014-2017 } \\
\text { (Jan-Sept } \\
\text { Average) }\end{array}$ & $\begin{array}{l}2018 \\
\text { (Jan-Sept } \\
\text { Average) }\end{array}$ \\
\hline
\end{tabular}

and geography but differ in their level of capacity, experienced different levels of recovery. We will present results both controlling and not controlling for these covariates in our analysis. Also, all standard errors are robust to heteroskedasticity.

\section{Results}

\subsection{Municipal Capacity's relationship to recovery}

Table 4 provides the results of regressing our relative measure of recovery against municipal capacity and the other covariates. Interestingly, the distance to the path of the hurricane is not a significant predictor of social and economic recovery, suggesting that municipalities that were hit harder do not necessarily show signs of slower recovery or underperformance compared to their previous trend. Other covariates, such as population density and poverty also do not predict the relative rate of recovery.

In terms of capacity, we find in columns (1) and (2) that capacity is positively correlated with recovery, although the effects are not statistically significant at conventional levels. However, columns (3) to (8) indicate that public engagement has a strong positive correlation with recovery. On average, a one standard deviation increase in the z-score for public engagement is associated with a 0.22 to 0.275 standard deviation increase in the overall recovery z-score, which is arguably a small effect size [62]. However, small effects sizes may be expected in studying the complex relationship between municipal capacity and recovery from major disasters. Further, we break down public engagement into the two sub-categories found in column (9): community involvement and public data access. We find that community involvement has a strong, positive correlation to recovery; similarly, a one standard deviation increase in this indicator is associated with a 0.271 standard deviation increase in the recovery z-score. No other functional area shows a statistically significant relationship with recovery.

Next, we investigate how capacity relates to each socio-economic indicator in Table 2, in order to assess whether the effect of capacity is centered on specific dimensions. We ran separate regressions, with the full set of controls, using the overall capacity score, and the scores in the four key areas (jointly). The coefficient on capacity in the first set of regressions are shown in the first panel of Table 4. The coefficients on the four key areas in the second set of regressions are shown in the second panel.

The findings indicate that higher public engagement capacity matters more for increasing the labor force and total employment than other factors. This relationship is relatively unexplored in the literature, however our finding provides a motivation for further research. Hurricane recovery activity is associated with improved economic conditions in some areas [63]. Public engagement may help target aid where it is most needed and help residents access government aid more quickly [38]. Engagement may also help communities plan and provide mutual support for temporary disruption and remain in their residence. For example, people not evacuated from their residences were more likely to be employed more quickly after Hurricane Katrina [43]. 


\begin{tabular}{|c|c|c|c|}
\hline \multicolumn{4}{|c|}{ CAPACITY INDEX } \\
\hline Planning & Public Engagement & Operations & Finance/Administration \\
\hline $\begin{array}{l}\text { 1. \# professional staff in } \\
\text { Emergency Mgmt }\end{array}$ & Community Involvement & Permitting & Federal funds capacity \\
\hline $\begin{array}{l}\text { 2. \# professional staff in } \\
\text { Climate adaptation }\end{array}$ & $\begin{array}{l}\text { 1. \# professional staff in } \\
\text { Community Development }\end{array}$ & $\begin{array}{l}\text { 1. Land use review and } \\
\text { permitting provided? }\end{array}$ & $\begin{array}{l}\text { 1. Federal funds per capita ( } 5 y r \\
\text { avg) }\end{array}$ \\
\hline $\begin{array}{l}\text { 3. \# professional staff in } \\
\text { Planning }\end{array}$ & $\begin{array}{l}\text { 2. Individual citizens involved in } \\
\text { planning services? }\end{array}$ & 2. Municipal permit office? & Contracting \\
\hline $\begin{array}{l}\text { 4. \# professional staff in } \\
\text { Economic Development }\end{array}$ & $\begin{array}{l}\text { 3. Individual citizens involved in } \\
\text { designing services? }\end{array}$ & Human Resources & 1. Supplier registry? \\
\hline \multirow[t]{16}{*}{$\begin{array}{l}\text { 5. Comprehensive Land Use } \\
\text { Planning provided? }\end{array}$} & $\begin{array}{l}\text { 4. Individual citizens involved in } \\
\text { delivering services? }\end{array}$ & $\begin{array}{l}\text { 1. Able to fill vacancies with } \\
\text { qualified individuals }\end{array}$ & $\begin{array}{l}\text { 2. Online vendor portal/ } \\
\text { registration? }\end{array}$ \\
\hline & $\begin{array}{l}\text { 5. Individual citizens involved in } \\
\text { assessing services? }\end{array}$ & $\begin{array}{l}\text { 2. \% of employees in regular or } \\
\text { trust positions }\end{array}$ & $\begin{array}{l}\text { Experience with investment } \\
\text { projects }\end{array}$ \\
\hline & $\begin{array}{l}\text { 6. Associations involved in local } \\
\text { govt? }\end{array}$ & $\begin{array}{l}\text { 3. \# professional staff in public } \\
\text { admin }\end{array}$ & $\begin{array}{l}\text { 1. \% changes in investment in } \\
\text { capital assets (all funds, 2009- } \\
2015 \text { ) }\end{array}$ \\
\hline & $\begin{array}{l}\text { 7. Online citizen engagement and } \\
\text { resident comment? }\end{array}$ & Inspection & $\begin{array}{l}\text { 2. Investment in capital assets } \\
\text { (as \% of consolidated funds, } \\
\text { 2015) }\end{array}$ \\
\hline & Public Data Access & $\begin{array}{l}\text { 1. Inspection/code enforcement } \\
\text { for construction provided? }\end{array}$ & $\begin{array}{l}\text { 3. \% change in budgeted } \\
\text { investment in capital } \\
\text { improvements in General Fund } \\
\text { (FY } 2017 \text { vs. FY 2013) }\end{array}$ \\
\hline & $\begin{array}{l}\text { 1. Online access to public/financial } \\
\text { docs }\end{array}$ & $\begin{array}{l}\text { 2. Inspections during } \\
\text { reconstruction periods? }\end{array}$ & $\begin{array}{l}\text { 4. Budgeted investment in } \\
\text { capital improvements in General } \\
\text { Fund (FY2017) }\end{array}$ \\
\hline & $\begin{array}{l}\text { 2. Online viewing of legislative } \\
\text { meetings }\end{array}$ & $\begin{array}{l}\text { 3. Need of additional support in } \\
\text { public works (planning/ } \\
\text { engineers/inspectors) }\end{array}$ & Financial Health \\
\hline & $\begin{array}{l}\text { 3. Online project plan review } \\
\text { submission }\end{array}$ & $\begin{array}{l}\text { 4. \# professional staff in building } \\
\text { inspection/code enforcement }\end{array}$ & $\begin{array}{l}\text { 1. Balance in General Fund (\% } \\
\text { General Revenues FY2016) }\end{array}$ \\
\hline & $\begin{array}{l}\text { 4. How community kept informed } \\
\text { about recovery process }\end{array}$ & & $\begin{array}{l}\text { 2. Ratio revenues/expenses in GF } \\
\text { (FY2012-16) }\end{array}$ \\
\hline & $\begin{array}{l}\text { 5. Did auditors have adverse } \\
\text { opinion regarding capital assets } \\
\text { recording in FY2016? }\end{array}$ & & Financial planning \\
\hline & & & $\begin{array}{l}\text { 1. Frequency of financial } \\
\text { statements }\end{array}$ \\
\hline & & & $\begin{array}{l}\text { 2. Frequency of financial } \\
\text { projections }\end{array}$ \\
\hline & & & $\begin{array}{l}\text { 3. Yearly operating budget } \\
\text { adopted prior to authorizing tax } \\
\text { rate? }\end{array}$ \\
\hline & & & $\begin{array}{l}\text { 4. Yearly capital budget adopted } \\
\text { prior to authorizing tax rate? }\end{array}$ \\
\hline & & & $\begin{array}{l}\text { 5. \# professional staff in } \\
\text { Financial Mgmt }\end{array}$ \\
\hline & & & $\begin{array}{l}\text { 6. Avg budgeted vs realized } \\
\text { income in GF (2013-18) }\end{array}$ \\
\hline
\end{tabular}

Fig. 2. Components of the Puerto Rico municipal capacity index.

Table 2

Average deviation from 2018 expected values.

\begin{tabular}{lllll}
\hline & Mean & $\begin{array}{l}\text { Std. } \\
\text { Err. }\end{array}$ & \multicolumn{2}{l}{\begin{tabular}{l} 
95\% Confidence Interval \\
\cline { 5 - 5 }
\end{tabular}} \\
& & & $\begin{array}{l}\text { Lower } \\
\text { limit }\end{array}$ & $\begin{array}{l}\text { Upper } \\
\text { limit }\end{array}$ \\
\hline Mortality Rate & 0.56 & 2.85 & -5.11 & 6.23 \\
Crime Rate & -0.57 & 0.26 & -1.09 & -0.06 \\
Unemployment rate & 0.11 & 0.17 & -0.23 & 0.45 \\
Population (difference in \%) & -2.35 & 0.03 & -2.41 & -2.30 \\
Business Units (difference in \%) & -0.82 & 0.55 & -1.91 & 0.27 \\
Quarterly Wages (difference in & 4.32 & 0.68 & 2.95 & 5.68 \\
$\quad$ \%) & & & & \\
$\quad$ Labor Force (difference in \%) & -1.06 & 0.33 & -1.72 & -0.39 \\
Employment (difference in \%) & -1.28 & 0.35 & -1.98 & -0.58 \\
\hline
\end{tabular}

It is worth noting that higher capacity scores in finance and administration are associated with lower recovery in labor force, employment, mortality, and change in population. However, these effects are smaller and are not statistically significant (even at the $10 \%$ level) when the finance and administration score is included by itself in the regression without the other key areas. In contrast, the positive and significant effects of the public engagement score are robust to whether this variable is included with or without the scores in the other key areas. Thus, it is possible that multicollinearity may be driving the statistically significant negative coefficients on finance and administration in Table 4. The same could be said about the positive relationship between overall capacity and reductions in population, which appear to be driven by the finance and administration score. In general, overall capacity only appears associated with reductions in crime, but this relationship is significant at the $10 \%$ level.

\section{Limitations and lessons for analyses of recovery from catastrophic disasters}

There are inherent limitations to how we calculate municipal capacity and how we measure recovery. These limitations generally take three forms: data quality and availability, whether the data were appropriate measures, and whether composite indices reflect the underlying phenomenon.

We found that very limited data existed covering all 78 municipalities, and even when it existed, it was often not available for all of the time periods we sought. Data available directly from municipalities was also limited, both by the lack of depth in the survey instrument used in Nuñez-Neto et al. [8] which aimed more at breadth, and by municipal officials' self-reports. However, these limitations may negate one another: because officials were generally only asked for basic information about whether services or personnel existed, and not about their quality or effectiveness, the survey data lacked detail that would have 
Table 3

Relative recovery regressed against municipal capacity and other covariates.

\begin{tabular}{|c|c|c|c|c|c|c|c|c|}
\hline & \multicolumn{8}{|c|}{ Outcome: Index of deviations from trend in 2018 values (z-score) } \\
\hline & (1) & (2) & (3) & (4) & (5) & (7) & (8) & (9) \\
\hline Overall capacity score & $\begin{array}{l}0.134 \\
(0.106)\end{array}$ & $\begin{array}{l}0.037 \\
(0.117)\end{array}$ & - & - & - & - & - & - \\
\hline Planning score & - & - & $\begin{array}{l}-0.004 \\
(0.123)\end{array}$ & - & - & - & $\begin{array}{l}0.003 \\
(0.116)\end{array}$ & $\begin{array}{l}0.011 \\
(0.114)\end{array}$ \\
\hline Public Engagement Score & - & - & - & $\begin{array}{l}0.222 * * \\
(0.095)\end{array}$ & - & - & $\begin{array}{l}0.275^{* *} \\
(0.108)\end{array}$ & - \\
\hline Community Involvement & - & - & - & - & - & - & - & $\begin{array}{l}0.271^{* *} \\
(0.118)\end{array}$ \\
\hline Public Data Access & - & - & - & - & - & - & - & $\begin{array}{l}0.050 \\
(0.121)\end{array}$ \\
\hline Operations score & - & - & - & - & $\begin{array}{l}-0.091 \\
(0.128)\end{array}$ & - & $\begin{array}{l}-0.094 \\
(0.133)\end{array}$ & $\begin{array}{l}-0.073 \\
(0.134)\end{array}$ \\
\hline Finance \& Admin score & - & - & - & - & - & $\begin{array}{l}-0.069 \\
(0.112)\end{array}$ & $\begin{array}{l}-0.137 \\
(0.115)\end{array}$ & $\begin{array}{l}-0.135 \\
(0.112)\end{array}$ \\
\hline Min distance $(\mathrm{km})$ & $\begin{array}{c}-0.002 \\
(0.007)\end{array}$ & $\begin{array}{l}0.004 \\
(0.007)\end{array}$ & $\begin{array}{l}0.005 \\
(0.007)\end{array}$ & $\begin{array}{l}0.004 \\
(0.007)\end{array}$ & $\begin{array}{l}0.004 \\
(0.007)\end{array}$ & $\begin{array}{l}0.004 \\
(0.007)\end{array}$ & $\begin{array}{l}0.003 \\
(0.007)\end{array}$ & $\begin{array}{l}0.002 \\
(0.007)\end{array}$ \\
\hline Interior Municipality & - & $\begin{array}{l}-0.116 \\
(0.238)\end{array}$ & $\begin{array}{l}-0.111 \\
(0.240)\end{array}$ & $\begin{array}{l}-0.099 \\
(0.236)\end{array}$ & $\begin{array}{l}-0.106 \\
(0.237)\end{array}$ & $\begin{array}{l}-0.108 \\
(0.231)\end{array}$ & $\begin{array}{l}-0.082 \\
(0.237)\end{array}$ & $\begin{array}{l}-0.117 \\
(0.234)\end{array}$ \\
\hline Poverty level & - & $\begin{array}{l}0.037 \\
(0.032)\end{array}$ & $\begin{array}{l}0.036 \\
(0.031)\end{array}$ & $\begin{array}{l}0.035 \\
(0.030)\end{array}$ & $\begin{array}{l}0.037 \\
(0.031)\end{array}$ & $\begin{array}{l}0.035 \\
(0.032)\end{array}$ & $\begin{array}{l}0.032 \\
(0.030)\end{array}$ & $\begin{array}{l}0.033 \\
(0.030)\end{array}$ \\
\hline Ln(Population per sq miles) & - & $\begin{array}{l}0.625 \\
(0.384)\end{array}$ & $\begin{array}{l}0.647 \\
(0.403)\end{array}$ & $\begin{array}{l}0.579 * \\
(0.343)\end{array}$ & $\begin{array}{l}0.709 \\
(0.430)\end{array}$ & $\begin{array}{l}0.634 \\
(0.387)\end{array}$ & $\begin{array}{l}0.609 \\
(0.428)\end{array}$ & $\begin{array}{l}0.598 \\
(0.414)\end{array}$ \\
\hline Constant & $\begin{array}{l}0.052 \\
(0.202)\end{array}$ & $\begin{array}{l}-6.081 \\
(4.176)\end{array}$ & $\begin{array}{l}-6.205 \\
(4.294)\end{array}$ & $\begin{array}{l}-5.707 \\
(3.827)\end{array}$ & $\begin{array}{l}-6.645 \\
(4.481)\end{array}$ & $\begin{array}{l}-6.025 \\
(4.269)\end{array}$ & $\begin{array}{l}-5.720 \\
(4.420)\end{array}$ & $\begin{array}{l}-5.671 \\
(4.292)\end{array}$ \\
\hline Observations & 78 & 78 & 78 & 78 & 78 & 78 & 78 & 78 \\
\hline R-squared & 0.020 & 0.144 & 0.143 & 0.190 & 0.149 & 0.148 & 0.217 & 0.221 \\
\hline
\end{tabular}

Robust standard errors in parentheses.

$* * * \mathrm{p}<0.01, * * \mathrm{p}<0.05,{ }^{*} \mathrm{p}<0.1$.

Table 4

Capacity regressed against individual socio-economic indicators.

\begin{tabular}{|c|c|c|c|c|c|c|c|c|}
\hline \multirow[t]{2}{*}{ VARIABLES } & \multirow[t]{2}{*}{$\begin{array}{l}\text { Mortality } \\
\text { Rate }\end{array}$} & \multirow[t]{2}{*}{$\begin{array}{l}\text { Crime } \\
\text { Rate }\end{array}$} & \multirow{2}{*}{$\begin{array}{l}\text { Population } \\
\text { (difference in } \\
\% \text { ) }\end{array}$} & \multirow{2}{*}{$\begin{array}{l}\text { Business Units } \\
\text { (difference in } \\
\% \text { ) }\end{array}$} & \multirow{2}{*}{$\begin{array}{l}\text { Quarterly } \\
\text { Wages } \\
\text { (difference in } \\
\% \text { ) }\end{array}$} & \multirow{2}{*}{$\begin{array}{l}\text { Labor Force } \\
\text { (difference in } \\
\% \text { ) }\end{array}$} & \multirow{2}{*}{$\begin{array}{l}\text { Employment } \\
\text { (difference in } \\
\% \text { ) }\end{array}$} & \multirow[t]{2}{*}{$\begin{array}{l}\text { Unemploy-ment } \\
\text { rate }\end{array}$} \\
\hline & & & & & & & & \\
\hline \multicolumn{9}{|l|}{ PANEL 1} \\
\hline Overall capacity score & $\begin{array}{l}-1.407 \\
(2.991)\end{array}$ & $\begin{array}{l}-0.467 * \\
(0.276)\end{array}$ & $\begin{array}{l}-0.054 * * \\
(0.026)\end{array}$ & $\begin{array}{l}-0.087 \\
(0.676)\end{array}$ & $\begin{array}{l}-0.114 \\
(0.754)\end{array}$ & $\begin{array}{l}0.262 \\
(0.311)\end{array}$ & $\begin{array}{l}0.200 \\
(0.302)\end{array}$ & $\begin{array}{l}0.054 \\
(0.162)\end{array}$ \\
\hline \multicolumn{9}{|l|}{ PANEL 2} \\
\hline Planning score & $\begin{array}{l}0.170 \\
(2.968)\end{array}$ & $\begin{array}{l}-0.274 \\
(0.271)\end{array}$ & $\begin{array}{l}-0.011 \\
(0.041)\end{array}$ & $\begin{array}{l}-0.029 \\
(0.733)\end{array}$ & $\begin{array}{l}0.234 \\
(0.782)\end{array}$ & $\begin{array}{l}-0.354 \\
(0.267)\end{array}$ & $\begin{array}{l}-0.187 \\
(0.274)\end{array}$ & $\begin{array}{l}-0.131 \\
(0.168)\end{array}$ \\
\hline $\begin{array}{l}\text { Public Engagement } \\
\text { Score }\end{array}$ & $\begin{array}{l}2.721 \\
(3.879)\end{array}$ & $\begin{array}{l}0.055 \\
(0.307)\end{array}$ & $\begin{array}{l}0.035 \\
(0.029)\end{array}$ & $\begin{array}{l}1.050 \\
(0.651)\end{array}$ & $\begin{array}{l}-0.390 \\
(0.550)\end{array}$ & $\begin{array}{l}1.251^{* * *} \\
(0.331)\end{array}$ & $\begin{array}{l}1.113^{* * *} \\
(0.303)\end{array}$ & $\begin{array}{l}0.034 \\
(0.176)\end{array}$ \\
\hline Operations score & $\begin{array}{l}1.241 \\
(3.260)\end{array}$ & $\begin{array}{l}-0.391 \\
(0.323)\end{array}$ & $\begin{array}{r}-0.040 \\
(0.039)\end{array}$ & $\begin{array}{c}-0.603 \\
(0.710)\end{array}$ & $\begin{array}{r}-0.079 \\
(0.864)\end{array}$ & $\begin{array}{l}0.065 \\
(0.326)\end{array}$ & $\begin{array}{l}-0.107 \\
(0.308)\end{array}$ & $\begin{array}{l}0.186 \\
(0.187)\end{array}$ \\
\hline Finance \& Admin score & $\begin{array}{l}-5.157^{*} \\
(3.066)\end{array}$ & $\begin{array}{l}-0.127 \\
(0.302)\end{array}$ & $\begin{array}{l}-0.061 * \\
(0.035)\end{array}$ & $\begin{array}{l}-0.596 \\
(0.563)\end{array}$ & $\begin{array}{l}0.069 \\
(0.620)\end{array}$ & $\begin{array}{l}-0.545^{*} \\
(0.284)\end{array}$ & $\begin{array}{l}-0.516^{*} \\
(0.301)\end{array}$ & $\begin{array}{l}0.014 \\
(0.173)\end{array}$ \\
\hline
\end{tabular}

Robust standard errors in parentheses.

$* * * \mathrm{p}<0.01, * * \mathrm{p}<0.05, * \mathrm{p}<0.1$.

been useful for analysis, but responses were less likely to be biased or self-serving.

Data quality may also have varied across municipalities for any number of reasons. We attempted to obtain the highest quality data possible by using data collected directly for Nuñez-Neto et al. [8] or by using Commonwealth-level sources which were subject to stricter validation. ${ }^{3}$ However, due to the severe impacts of the hurricanes on Puerto Rico, the quality of post-hurricane data could have been adversely affected by the storms. We do not have evidence that this was the case,

\footnotetext{
${ }^{3}$ As noted above, several of the authors of this article are also authors of Nuñez-Neto [8] and participated in the design of the municipal survey used in that study and data collection using the survey instrument.
}

but it is reasonable to assume that some measures we relied on, such as crime, may have been underreported after the hurricanes, and that the quality of reporting could have varied across municipalities.

Even where data were available, we may not have selected the best indicators for measuring capacity or recovery. We attempted to account for variation in exposure to the storm as this could have had a significant impact on damages incurred, but our controls were inherently limited. We used the same capacity and recovery indicators for all municipalities, but there may be reasons to treat municipalities with different characteristics differently. For example, some of the elements of capacity we measured may be more or less important based on a municipality's topography, population density, or other factors. The measures we selected may not have been accurate representations of municipal capacity or may have measured capacities which are not likely to be 
associated with the traits needed to reduce damage from hurricanes and recover more rapidly. Similarly, the recovery indicators we selected may not be appropriate measures of recovery and could instead reflect some other aspect of municipal well-being. Some of those indicators could be influenced, positively or negatively, by recovery activities. For example, as we note above, economic activity may have increased following the storms simply as a result of the large number of reconstruction projects needed and may not reflect underlying municipal fiscal health or sustained employment activity. Some indicators may be influenced more by external factors which impact every municipality, such as national economic trends, than by an individual municipal government's actions.

In controlling for exposure, we used distance as a proxy, but other factors contribute to exposure, including wind speed, building quality, and other aspects of geography. Sufficient data were not available to control for these factors. In addition, indicators could be correlated with or otherwise impact one another; for example, increases in crime may have negative impacts on economic activity.

This analysis employs small number of indicators, particularly for recovery, both by choice and often by necessity. As a result, the selection of any single indicator may have outsize influence on our results in a way that indices which rely on a very large number of indicators do not. A related benefit, however, is that unlike many other indices, these measures are easily understandable in practical, real-world terms that resonate with citizens. These indicators may be applicable in future locations and emergencies where data limitations exist. Ideally, however, the recovery measures would have included other facets of municipal well-being suggested by the research literature, such as infrastructure.

Lastly, recovery is a long-term process, generally understood to span multiple years. We were restricted to assessing near-term recovery from Maria; as additional longitudinal data become available, a longer-term assessment of municipal recovery will be possible.

\section{Discussion and conclusion}

Our project contributes to the understanding of the role of municipal capacity, and community engagement in particular, in advancing disaster recovery. The role of municipal capacity has perhaps been overshadowed by attention to national government, states or provinces, non-profits and NGOs, or even social capital in hastening recovery. Municipalities play an important role linking these groups. We also offer observations about how to analyze recovery given data availability limitations, time pressure, and perishable data.

We developed measures for pre-storm municipal capacity and postdisaster recovery using a relatively small number of bellwether indicators. Although we relied in part on a large-scale, unprecedented post-storm data collection effort to measure capacity, we measured recovery using the relatively small number of measures available in postMaria Puerto Rico that were frequently updated and likely to be available island-wide. The lack of quantitative data limits post-disaster research in the Caribbean, and the region would benefit from efforts to build longitudinal indicators relevant to disaster resilience and recovery [64].

Although Maria had devastating impacts on virtually every community in Puerto Rico, we controlled for exposure to the storm by using municipalities' distance to the hurricane centroid, which we found was highly correlated to FEMA Verified Losses over $\$ 5000$. We also accounted for inherent geographic and other differences across municipalities and accounted for difference in pre-storm performance on key recovery indicators to attempt to isolate the effects of pre-storm municipal capacity. We measured different aspects of municipal capacity to better understand what factors may be most important. This general research approach and the data underlying it is likely repeatable in other communities using readily available data. Puerto Rico may have relatively less data available than some states or municipalities with which it is compared in the United States, however other locations around the world may have similar or greater data availability challenges.

We found that only public engagement, composed of measures of community involvement and public access to data, appears significantly linked to recovery. When reported separately in Table 3 , community involvement achieves statistical significance, but public access does not. Municipal governments that successfully engage their constituents may be able to initiate recovery projects earlier than those that do not. The literature on disaster recovery suggests that effective community engagement is a key component of successful recoveries and that a lack of effective community engagement can lead to problems in recovery [41,65-68]. Engagement occurs through community involvement in designing, managing, and delivering public services. It is also associated with staff and programs within municipalities to engage in community development by holding meetings, developing contact lists or websites, and initiating new programs. Engagement may stimulate or be associated with social capital, including the trust, norms, and networks to outside resources that have been shown to be associated with recovery and resilience [7,22]; Roque, Pijawka, and Wutich 2020; [70].

In Puerto Rico, community engagement combined with other elements of municipal capacity may have allowed engaged municipalities to start recovery projects sooner. Quarterly wages are higher after the hurricane relative to pre-storm trends, which suggests a reconstruction spending and employment bump. Municipal capacity may provide the foundation for faster spending on recovery projects, new jobs, and increased employment, though future studies will have to investigate the causal linkage.

There are many possible links between capacity and faster recovery. Municipalities with greater capacity for community engagement prior to disasters may simply be more likely to have greater capacity after disasters [71]. It is also possible that municipalities with greater community engagement capacity prior to disasters may have developed stronger relationships with their communities as a result prior to disaster, so that when disaster strikes, they are able to leverage these relationships. Indeed, Nuñez-Neto et al.'s [8]; 86) report mentions that, "services provided by nongovernmental organizations [including nonprofit organizations, organized volunteers, and others] played a key role immediately after the hurricane." It is possible that improved recovery outcomes are due to a number of intertwined factors: underlying municipal capacity, the effects of pre-disaster outcomes from capacity on recovery, and the social capital that results from both. Our findings provide evidence that municipal programs to enhance community engagement may be an important part of social capital.

We did not find that management capacity at the municipal level more broadly is associated with faster recovery, however. Our null finding contributes to debates in the literature by showing that the effects may be too small to measure, or that additional measures should be analyzed. Public management and natural hazards scholars emphasize the importance of managerial capacity in local governments [72,73], but evidence for its effects on outcomes is limited. Exceptions include Andrews and Boyne's [74] study of general public management and de Loe et al.'s [75] findings concerning groundwater protection. Public engagement may be a particularly important form of management capacity for disaster preparedness.

\subsection{Implications for policy}

Our findings point to an opportunity to fund public engagement to improve resilience and recovery. Communities might invest in predisaster capacity for community engagement in order to reap benefits during recovery in the future. Scholars and policy advocates have called on government policies to be more pro-active to reduce disaster losses in advance rather than reactive, spending to help survivors after an event [76].

Funding for resilience is often associated with specific systems and infrastructure and is rarely provided to shore up basic municipal government capacity or promote community engagement. Disaster recovery 
funds, by definition are typically available only after a disaster has occurred.

In an alternative approach consistent with our findings, technical assistance funds could be made available for community engagement programs. This assistance could include models from other communities for providing public access to data, promoting community involvement, and providing education about buyouts, restoration, and government and nonprofit aid. Local authorities are in the best position to engage residents and determine pre-and post-disaster needs. Some other forms of capacity such as technical assistance or logistics can be provided after disaster by state, territorial, or federal authorities, but local government's particular expertise is in engaging residents. Other forms of municipal capacity may matter for recovery and deserve research in future studies. For example, building code enforcement may be associated with faster recovery times, but many code studies have focused on earthquakes rather than hurricanes (e.g., Ref. [77].

\subsection{Implications for future research}

Future research could measure municipal capacity differently in two ways. First, having access to, or collecting, better data would be useful to measure capacity more accurately and to differentiate among specific aspects of municipal capacity to identify and prioritize the most important. Second, data could be collected on capacities that are believed to be more closely related to emergency management, hazard mitigation, preparedness, response, and recovery to contrast the impact of these capacities with the impact of more general, non-disaster specific, municipal capacity and to assess the correlation between disasterspecific and non-disaster-specific municipal capacity.

Scholars of post-disaster recovery could collect data to measure recovery more comprehensively to determine if richer measures provide different insights than our more parsimonious approach (e.g., Ref. [78]. Indicators tied to FEMA's recovery support functions and local pre-disaster recovery plans may prove to be particularly rich where the data are available [79]. In Puerto Rico's relatively sparse data environment, we relied on a set of bellwether indicators which were available for each of Puerto Rico's 78 municipalities, which necessarily led to the exclusion of some key elements of recovery which would have ideally been included and are suggested by the research literature, such as measures related to infrastructure recovery. ${ }^{4}$ However, as noted above, we also argue that this is a potential strength of our approach. A similar assessment could be performed after any disaster; rather than relying on a pre-identified set of indicators, our findings suggest that it may be possible to identify meaningful differences in recovery relative to pre-disaster trends and relative to peer communities simply by using available data.

Our work shows that assessing recovery does not require a new data collection effort to identify recovery-specific indicators. Existing data, such as data from 311 systems and other municipal performance data, may be equally effective. In our study, using a small number of readily available indicators that may already be meaningful to both government officials and the public increases transparency and makes replication relatively straightforward.

\section{Declaration of competing interest}

The authors declare that they have no known competing financial

\footnotetext{
${ }^{4}$ Indicators for future research include: more detailed measures of social cohesion, such as community satisfaction surveys; economic measures such as municipal GDP, business starts and closures, and real estate value; infrastructure measures such as road condition, water quality, or cellular and internet access; measures of institutional health, such as financial audit scores and government performance data such as 911 response times; and indicators of natural health including measures of pollution.
}

interests or personal relationships that could have appeared to influence the work reported in this paper.

\section{Appendix A. Supplementary data}

Supplementary data to this article can be found online at https://doi. org/10.1016/j.ijdrr.2021.102340.

\section{References}

[1] Louise Comfort, Ben Wisner, Susan Cutter, Roger Pulwarty, Kenneth Hewitt, Anthony Oliver-Smith, John Wiener, Maureen Fordham, Walter Peacock, Fred Krimgold, Reframing disaster policy: the global evolution of vulnerable communities, Global Environ. Change B Environ. Hazards 1 (1) (1999) 39-44.

[2] L.A. Johnson, R.B. Olshansky, After Great Disasters: an In-Depth Analysis of How Six Countries Managed Community Recovery, Lincoln Institute of Land Policy, Cambridge, 2017.

[3] L.A. Johnson, Developing a local recovery management framework: report on the post-disaster strategies and approaches taken by three local governments in the US following major disasters, Int. J. Mass Emergencies Disasters 32 (2) (2014) 242-274.

[4] Gregory A. Bigley, Karlene H. Roberts, The incident command system: highreliability organizing for complex and volatile task environments, Acad. Manag. J. 44 (6) (2001) 1281-1299.

[5] P.W. Ingraham, A.K. Donahue, Dissecting the black box revisited: characterizing government management capacity, Govern. Perform.: New Perspect. (2000) 292-318.

[6] C.G. Burton, A validation of metrics for community resilience to natural hazard and disasters using the recovery from Hurricane Katrina as a case study, Ann. Assoc. Am. Geogr. 105 (1) (2015) 67-86.

[7] D.P. Aldrich, Black Wave: How Networks and Governance Shaped Japan's 3/11 Disasters, University of Chicago Press, 2019.

[8] B. Nuñez-Neto, A. Lauland, J. Aguirre, G. Castro, I. Gutierrez, M. Lara, E. Rosas, B. Weidmer, Municipalities on the Front Lines of Puerto Rico's Recovery, RR-2604DHS, RAND Corporation, Santa Monica, CA, 2020.

[9] Center for Puerto Rican Studies, Rebuild Puerto Rico: A Guide to Federal Policy and Advocacy, 2018. As of March 3, 2020, https://centropr.hunter.cuny.edu/events-ne ws/rebuild-puerto-rico/policy/rebuild-puerto-rico-guide-federal-policy-and-advo cacy.

[10] C.D. Zorrilla, The view from Puerto Rico-hurricane Maria and its aftermath, N. Engl. J. Med. 377 (19) (2017) 1801-1803.

[11] L.M. Killian, An introduction to methodological problems of field studies in disasters, in: R.A. Stallings (Ed.), Methods of Disaster Research, 2002, pp. 49-93 (Bloomington, IN: Xlibris).

[12] Evan Berman, XiaoHu Wang, Performance measurement in US counties: capacity for reform, Publ. Adm. Rev. 60 (5) (2000) 409-420.

[13] Shelly Culbertson, John Bordeaux, Italo A. Gutierrez, Andrew lauland, kristin leuschner, blas nuñez-neto, and lisa saum-Manning, in: Building Back Locally: Supporting Puerto Rico's Municipalities in Post-Hurricane Reconstruction, The RAND Corporation, Santa Monica, CA, 2020. RR-3041-DHS.

[14] M. Sicilia, A. Sancino, T. Nabatchi, E. Guarini, Facilitating co-production in public services: management implications from a systematic literature review, Publ. Money Manag. 39 (4) (2019) 233-240.

[15] J.K. Mitchell, The primacy of partnership: scoping a new national disaster recovery policy, Ann. Am. Acad. Polit. Soc. Sci. 604 (1) (2006) 228-255.

[16] D.J. Alesch, Complex urban systems and extreme events: toward a theory of disaster recovery, in: Proceedings of the 1st International Conference on Urban Disaster Reduction, Earthquake Engineering Research Institute, Kobe, Japan, 2005, 2005.

[17] G. Smith, D. Wenger, Sustainable disaster recovery: operationalizing an existing agenda, in: H. Rodriguez, E.L. Quarantelli, R. Dynes (Eds.), Handbook of Disaster Research, Springer, New York, 2007, pp. 234-257.

[18] R.B. Olshansky, L.D. Hopkins, L.A. Johnson, Disaster and recovery: processes compressed in time, Nat. Hazards Rev. 13 (3) (2012) 173-178.

[19] N. Kapucu, C.V. Hawkins, F.I. Rivera, Disaster resiliency: interdisciplinary perspectives, in: Disaster Resiliency, Routledge, 2013, pp. 23-36.

[20] S.L. Cutter, B.J. Boruff, W.L. Shirley, Social vulnerability to environmental hazards, Soc. Sci. Q. 84 (2) (2003) 242-261.

[21] S. Vallance, S. Carlton, First to respond, last to leave: communities' roles and resilience across the '4Rs', Int. J. Disast. Risk Reduct. 14 (2015) 27-36.

[22] D.P. Aldrich, Building Resilience: Social Capital in Post-disaster Recovery, University of Chicago Press, 2012.

[23] D.P. Aldrich, M.A. Meyer, Social capital and community resilience, Am. Behav. Sci. 59 (2) (2015) 254-269.

[25] N.E. Ganapati, In good company: why social capital matters for women during disaster recovery, Publ. Adm. Rev. 72 (3) (2012) 419-427.

[26] R. Islam, G. Walkerden, How bonding and bridging networks contribute to disaster resilience and recovery on the Bangladeshi coast, Int. J. Disast. Risk Reduct. 10 (2014) 281-291.

[28] Y. Nakagawa, R. Shaw, Social capital: a missing link to disaster recovery, Int. J. Mass Emergencies Disasters 22 (1) (2004) 5-34.

[29] D.P. Aldrich, Ties that bond, ties that build: social capital and governments in post disaster recovery, Stud. Emerg. Order 4 (December) (2011) 58-68. 
[30] R.B. Olshansky, L.A. Johnson, J. Horne, B. Nee, Longer view: planning for the rebuilding of new Orleans, J. Am. Plann. Assoc. 74 (3) (2008) 273-287.

[32] Unified New Orleans Plan (UNOP), Citywide Strategic Recovery and Rebuilding Plan, Unified New Orleans Plan, Adopted by New Orleans City Planning Commission, 2007.

[33] K. Ford, The Trouble with City Planning: what New Orleans Can Teach Us, Yale University Press, 2010.

[34] Trevor L. Brown, Matthew Potoski, Contract-management capacity in municipal and county governments, Publ. Adm. Rev. 63 (2) (2003) 153-164.

[35] M. Lodge, K. Wegrich (Eds.), The Problem-Solving Capacity of the Modern State: Governance Challenges and Administrative Capacities, Hertie Governance Report, Berlin, Germany, 2014.

[37] C. Polidano, Measuring public sector capacity, World Dev. 28 (5) (2000) 805-822.

[38] W.F. Chappell, R.G. Forgette, D.A. Swanson, M.V. Van Boening, Determinants of government aid to Katrina survivors: evidence from survey data, South. Econ. J. (2007) 344-362.

[39] T. Nabatchi, L.B. Amsler, Direct public engagement in local government, Am. Rev. Publ. Adm. 44 (4_suppl) (2014) 63S-88S.

[40] J.C. Thomas, Citizen, customer, partner: rethinking the place of the public in public management, Publ. Adm. Rev. 73 (6) (2013) 786-796.

[41] M. Mojtahedi, B.L. Oo, Critical attributes for proactive engagement of stakeholders in disaster risk management, Int. J. Disast. Risk Reduct. 21 (2017) 35-43.

[42] L. Uscher-Pines, A. Chandra, J. Acosta, A. Kellermann, Citizen preparedness for disasters: are current assumptions valid? Disaster Med. Public Health Prep. 6 (2) (2012) 170-173.

[43] J. Zissimopoulos, L.A. Karoly, Employment and self-employment in the wake of hurricane Katrina, Demography 47 (2) (2010) 345-367.

[44] S.G. Knowles, Learning from disaster? The history of technology and the future of disaster research, Technol. Cult. 55 (4) (2014) 773-784.

[45] M.M. Nelan, T. Wachtendorf, S. Penta, Agility in disaster relief: a social construction approach, Risk Hazards Crisis Publ. Pol. 9 (2) (2018) 132-150.

[46] D.R. Godschalk, Disaster Mitigation and Hazard management." Emergency Management: Principles and Practice for Local Government, International City Management Association, Washington, DC, 1991, pp. 131-160.

[47] J. Links, B. Schwartz, S. Lin, N. Kanarek, J. Mitrani-Reiser, T. Sell, C. Watson, D. Ward, C. Slemp, R. Burhans, K. Gill, T. Igusa, X. Zhao, B. Aguirre, J. Trainor, J. Nigg, T. Inglesby, C. Carbone, J. Kendra, COPEWELL: a conceptual framework and system dynamics model for predicting community functioning and resilience after disasters, Disaster Med. Public Health Prep. 12 (1) (2017) 127-137.

[48] D.F. Kettl, The Next Government of the United States: Why Our Institutions Fail Us and How to Fix Them, WW Norton \& Company, 2009.

[49] S.L. Cutter, The landscape of disaster resilience indicators in the USA, Nat. Hazards 80 (2) (2016) 741-758.

[50] Ben Wisner, et al., At Risk: Natural Hazards, People's Vulnerability and Disasters, Psychology Press, 2004.

[51] Omar D. Cardona, The need for rethinking the concepts of vulnerability and risk from a holistic perspective: a necessary review and criticism for effective risk management, Mapp. vulnerab.: Disast. Devel. Peopl. 17 (2004) 37-51.

[52] S. Platt, D. Brown, M. Hughes, Measuring resilience and recovery, Int. J. Disast. Risk Reduct. 19 (2016) 447-460.

[53] M. McGuire, C. Silvia, The effect of problem severity, managerial and organizational capacity, and agency structure on intergovernmental collaboration: evidence from local emergency management, Publ. Adm. Rev. (2) (2010) 279-288.

[54] H.G. Rainey, Understanding and Managing Public Organizations, John Wiley \& Sons, 2009, 2009.

[55] National Academies, Disaster Resilience, A National Imperative, Washington, DC, 2012.

[56] D.P. Aldrich, It's who you know: factors driving recovery from Japan's 11 March 2011 Disaster, Publ. Adm. 94 (2) (2016) 399-413, 2016.

[57] Frederick L. Bates, Walter Gillis Peacock, Long-term [disaster] recovery, Int. J. Mass Emergencies Disasters 7 (3) (1989) 349-365.

[58] J.D. Acosta, L. Burgette, A. Chandra, D.P. Eisenman, I. Gonzalez, D. Varda, L. Xenakis, How community and public health partnerships contribute to disaster recovery and resilience, Disaster Med. Public Health Prep. 12 (5) (2018) 635-643.

[59] A.M. Esnard, A. Sapat, Displaced by Disaster: Recovery and Resilience in a Globalizing World, Routledge, 2014.

[60] A. Curtis, J.W. Mills, Crime in urban post-disaster environments: a methodological framework from New Orleans, Urban Geogr. 32 (4) (2011) 488-510.

[61] Kelly Frailing, Dee Wood Harper Jr., Ronal Serpas, Changes and challenges in crime and criminal justice after disaster, Am. Behav. Sci. 59 (10) (2015) $1278-1291$.

[62] J. Cohen, Statistical Power for the Behavioral Sciences, second ed., Erlbaum, Hillsdale, NJ, 1988.
[63] B.T. Ewing, J.B. Kruse, The impact of project impact on the Wilmington, North Carolina, labor market, Publ. Finance Rev. 30 (4) (2002) 296-309.

[64] H.M. Louis-Charles, R. Howard, L. Remy, F. Nibbs, G. Turner, Ethical considerations for postdisaster fieldwork and data collection in the caribbean, Am. Behav. Sci. 64 (8) (2020) 1129-1144, https://doi.org/10.1177/ 0002764220938113.

[65] S. Ainuddin, D.P. Aldrich, J.K. Routray, S. Ainuddin, A. Achkazai, The need for local involvement: decentralization of disaster management institutions in Baluchistan, Pakistan, Int. J. Disast. Risk Reduct. 6 (2013) 50-58.

[66] A. Chandra, M. Williams, A. Plough, A. Stayton, K.B. Wells, M. Horta, J. Tang, Getting actionable about community resilience: the Los Angeles county community disaster resilience project, Am. J. Publ. Health 103 (7) (2013) 1181-1189.

[67] D. Johnston, J. Becker, D. Paton, Multi-agency community engagement during disaster recovery: lessons from two New Zealand earthquake events, Disaster Prev. Manag.: Int. J. 21 (2) (2012) 252-268.

[68] Y. Zhang, W. Drake, Planning for housing recovery after the 2008 wenchuan earthquake in China, in: Sapat, Esnard (Eds.), Coming Home after Disasters: Multiple Dimensions of Housing Recovery, Routledge, New York, 2017, pp. 191-207.

[70] A.M. Sadri, S.V. Ukkusuri, S. Lee, R. Clawson, D. Aldrich, M. Sapp Nelson, J. Seipel, D. Kelly, The role of social capital, personal networks, and emergency responders in post-disaster recovery and resilience: a study of rural communities in Indiana, Nat. Hazards 90 (3) (2018) 1377-1406.

[71] A.A. Shah, R. Shaw, J. Ye, M. Abid, S.M. Amir, A.K. Pervez, S. Naz, Current capacities, preparedness and needs of local institutions in dealing with disaster risk reduction in Khyber Pakhtunkhwa, Pakistan, Int. J. Disast. Risk Reduct. 34 (2019) 165-172.

[72] Jerrell D. Coggburn, Saundra K. Schneider, The quality of management and government performance: an empirical analysis of the American states, Pub. Admin. Rev. 63 (2) (2003) 206-213.

[73] P.W. Ingraham, P.G. Joyce, A. Kneedler Donahue, Government Performance: Why Management Matters, Taylor \& Francis, 2003.

[74] Rhys Andrews, George A. Boyne, Capacity, leadership, and organizational performance: testing the black box model of public management, Publ. Adm. Rev. 70 (3) (2010) 443-454.

[75] Rob C. de Loe, Sandra E. Di Giantomasso, Reid D. Kreutzwiser, Local capacity for groundwater protection in Ontario, Environ. Manag. 29 (2) (2002) 217-233.

[76] S. Frank, E. Gesick, D.G. Victor, Inviting Danger: How Federal Disaster, Insurance and Infrastructure Policies Are Magnifying the Harm of Climate Change, Brookings Institution, Washington, DC, 2021. March 21, 2021. As of 3/26/2021: htt ps://www.brookings.edu/research/inviting-danger-how-federal-disaster-in surance-and-infrastructure-policies-are-magnifying-the-harm-of-climate-change/.

[77] R.J. Burby, S.P. French, A.C. Nelson, Plans, code enforcement, and damage reduction: evidence from the Northridge earthquake, Earthq. Spectra 14 (1) (1998) 59-74.

[78] E. Jordan, A. Javernick-Will, Indicators of community recovery: content analysis and Delphi approach, Nat. Hazards Rev. 14 (1) (2013) 21-28.

[79] J. Horney, C. Dwyer, M. Aminto, P. Berke, G. Smith, Developing indicators to measure post-disaster community recovery in the United States, Disasters 41 (1) (2017) 124-149.

[80] X. Wang, C.V. Hawkins, N. Lebredo, E.V. Berman, Capacity to sustain sustainability: A study of US cities, Pub. Admin. Rev. 72 (6) (2012) 841-853.

[81] Coles E., Buckle P., Developing community resilience as a foundation for effective disaster recovery, The Australian Journal of Emergency Management 4 (19) 6-15.

[82] S.L. Cutter, K.D. Ash, C.T. Emrich, The geographies of community disaster resilience, Glob. Environ. Change 29 (2014) 65-77.

\section{Further reading}

[24] E. Coles, P. Buckle, Developing community resilience as a foundation for effective disaster recovery, Aust. J. Emerg. Manag. 19 (4) (2004) 6-15.

[27] S. Culbertson, B. Nuñez-Neto, J.D. Acosta, C.R. Cook, A. Lauland, K.J. Leuschner, S. Nataraj, B.L. Preston, S.A. Resetar, A.C. Resnick, P. Roberts, H.J. Shatz, Recovery in the U.S. Virgin Islands: Progress, Challenges, and Options for the Future. RRA282-1, RAND Corporation, Santa Monica, CA, 2020, p. 384

[31] S.L. Cutter, C.G. Burton, C.T. Emrich, Disaster resilience indicators for benchmarking baseline conditions, J. Homel. Secur. Emerg. Manag. 7 (1) (2010).

[36] Evan Berman, XiaoHu Wang, Performance measurement in US counties: capacity for reform, Publ. Adm. Rev. 60 (5) (2000) 409-420.

[69] D.P. Aldrich, Black Wave: How Networks and Governance Shaped Japan's 3/11 Disasters, University of Chicago Press, 2019. 